\title{
Comparison Between Predicted Duct Effectiveness from Proposed ASHRAE Standard 152P and Measured Field Data for Residential Forced Air Cooling Systems
}

\author{
Jeffrey A. Siegel \\ Jennifer A. McWilliams \\ lain S. Walker, Ph.D.
Indoor Environment Department
Lawrence Berkeley National laboratory
Berkeley, CA 94720 \\ Environmental Energy Technologies Division
}

April 2002

This work was supported by the Assistant Secretary for Energy Efficiency and Renewable Energy, Office of Building Technology, State and Community Programs, Office of Building Research and Standards, U.S. Department of Energy under Contract No. DE-AC03-76SF00098 and the California Institute for Energy Efficiency (CIEE), a research unit of the University of California. 


\title{
Comparison Between Predicted Duct Effectiveness from Proposed ASHRAE Standard 152P and Measured Field Data for Residential Forced Air Cooling Systems
}

\author{
Jeffrey A. Siegel \\ ASHRAE Student Member
}

\author{
Jennifer A. McWilliams
}

lain S. Walker, Ph.D.

ASHRAE Member

\begin{abstract}
The proposed ASHRAE Standard 152P "Method of Test for Determining the Design and Seasonal Efficiencies of Residential Thermal Distribution Systems" (ASHRAE 2002) has recently completed its second public review. As part of the standard development process, this study compares the forced air distribution system ratings provided by the public review draft of Standard 152P to measured field results. 58 field tests were performed on cooling systems in 11 homes in the summers of 1998 and 1999. Seven of these houses had standard attics with insulation on the attic floor and a well-vented attic space. The other four houses had unvented attics where the insulation is placed directly under the roof deck and the attic space is not deliberately vented. Each house was tested under a range of summer weather conditions at each particular site, and in some cases the amount of duct leakage was intentionally varied. The comparison between $152 P$ predicted efficiencies and the measured results includes evaluation of the effects of weather, duct location, thermal conditions, duct leakage, and system capacity. The results showed that the difference between measured delivery effectiveness and that calculated using proposed Standard 152P is about 5 percentage points if weather data, duct leakage and air handler flow are well known. However, the accuracy of the standard is strongly dependent on having good measurements of duct leakage and system airflow. Given that the uncertainty in the measured delivery effectiveness is typically also about 5 percentage points, the Standard 152P results are acceptably close to the measured data.
\end{abstract}

\section{INTRODUCTION}

Recent research has emphasized the importance of duct efficiency to residential energy use (e.g. Jump et al., 1996; Siegel et al., 1998, Davis et al., 1998). In response to these studies, ASHRAE has developed a test method for evaluating residential thermal distribution systems, and other agencies (such as the California Energy Commission (CEC)) have begun to include duct efficiency calculations in energy codes based on previous drafts of the ASHRAE procedure. As the methods used to calculate duct efficiencies in the proposed ASHRAE Standard (Standard 152P "Method of Test for Determining the Design and Seasonal Efficiencies of Residential Thermal Distribution Systems") become more widely accepted, it is important to evaluate how well they work and what inputs are most important to obtain good results. In any evaluation of a model, such as proposed Standard 152P, a central question is how much uncertainty is acceptable. The answer depends on the intended application of the model. Standard 152P was designed as a relative rating tool to be used in evaluating duct system design and seasonal performance for a particular house relative to a base case. It is not intended to match the daily performance of a specific house. Therefore we would like a high level of accuracy when weather variations have been removed from the calculation. The engineering judgment of the authors suggests that a 5\% uncertainty is acceptable for application of the standard. This value is consistent with the opinion of the ASHRAE 152P committee.

Several researchers have performed evaluation studies of proposed Standard 152P. Proctor (1998) conducted tests on a single house with central cooling. Proctor systematically introduced and sealed calibrated leaks on the 
supply and return side of the duct system and evaluated whether the proposed Standard 152P calculations predicted the correct change in measured delivery efficiency. His tests suggest that proposed Standard 152P was in agreement with measured data with 5 percentage points about half of the time (depending on outdoor temperature, time of day, and whether supply or return leakage was introduced into the system). Francisco and Palmiter (1998) compared proposed Standard152P modeled and measured heating system efficiencies in seven manufactured homes with three variants of the proposed Standard 152P calculation procedure: using all measured data and no defaults, using 152P default buffer zone temperatures, and using default buffer zone temperatures and an indirect measurement of duct leakage (the house pressure test). Their results suggest decreasing agreement as more default data is used and show less than $5 \%$ percentage point difference between modeled and measured for all cases. Francisco and Palmiter (2000) used different duct leakage measurement procedures on 10 houses (some with multiple leakage configurations) to examine the effect on agreement between measured duct delivery efficiency and proposed Standard 152P predicted efficiency. The results emphasize the importance of duct leakage to obtaining a correct answer from proposed Standard 152P.

In this paper, we compare the predicted results from proposed Standard 152P to measured data from 11 houses in cooling climates in California, Nevada, and Texas. The primary goal is to discern how well proposed Standard $152 \mathrm{P}$ works at predicting cooling Delivery Effectiveness (DE). Delivery Effectiveness is the ratio of energy that enters the house through the registers to the energy put into the distribution system by the heating or cooling equipment. Delivery Effectiveness is calculated as an intermediate parameter in Standard 152P that is then adjusted to estimate Distribution System Effectiveness (DSE). DSE adds to the DE the impact of unbalanced leakage on building infiltration, energy recovery from losses to buffer zones, and cycling effects. DE was used in this paper because the field tests did not include measurements of the change in ventilation rate caused by distribution system operation (the infiltration interaction), the change in energy flows between conditioned space and duct locations, or cycling effects.

The input for the 152P calculation of DE is slightly modified from the standard. We used total supply duct leakage, rather than duct leakage to outside, because distribution system airflows into the house were measured at the registers. Thus, leakage to inside is not accounted for in the measured energy delivery, even thought it can contribute useful conditioning of a home. For the purposes of this paper, the delivery effectiveness is more like the older ASHRAE definition in Chapter 28, Systems and Equipment Handbook (ASHRAE, 1996) of duct efficiency: the ratio of the energy intentionally delivered to the conditioned space through the supply registers to the energy delivered to the furnace plenum. Note that the strict ASHRAE definition of duct efficiency is integrated over a whole year of operation, but we are only measuring data over a few days.

\section{STANDARD 152P AND MEASURED EFFECTIVENESS CALCULATIONS}

The delivery effectiveness in standard $152 \mathrm{P}$ is calculated from a steady-state thermal balance on the duct system using the following equation to account for leakage and conduction losses from the ducts:

$$
D E_{152 P}=\frac{a_{s} Q_{e} \rho_{i n}}{E_{c a p}}\left(\frac{E_{c a p}}{Q_{e} \rho_{i n}}+\left(1-a_{r}\right)\left(h_{a m b, r}-h_{i n}\right)+a_{r} C_{p}\left(B_{r}-1\right) \Delta t_{r}+C_{p}\left(B_{s}-1\right)\left(t_{s p}-t_{a m b, s}\right)\right)
$$

where: $Q_{e}$ is the air handler flow $\left(\mathrm{m}^{3} / \mathrm{s}\right)$,

$a_{s}$ and $a_{r}$ are the fractions of supply and return duct air that does not leak out of the ducts to the exterior, expressed as fractions of $\mathrm{Q}_{\mathrm{e}}$,

$\rho_{\text {in }}$ is the density of indoor air $\left(\mathrm{kg} / \mathrm{m}^{3}\right)$,

$E_{c a p}$ is the cooling equipment total (sensible + latent) capacity (W),

$h_{a m b, r}$ is the enthalpy of the air surrounding the return ducts $(\mathrm{J} / \mathrm{kg})$,

$h_{i n}$ is the enthalpy of indoor air entering into the return register $(\mathrm{J} / \mathrm{kg})$,

$C_{p}$ is the specific heat of air $(\mathrm{J} / \mathrm{kgK})$,

$\Delta t_{r}$ is the temperature difference between the indoor air and air surrounding the return ducts $\left({ }^{\circ} \mathrm{C}\right)$,

$t_{s p}$ is the temperature of the air in the supply plenum $\left({ }^{\circ} \mathrm{C}\right)$,

$t_{a m b, s}$ is the temperature of air surrounding the supply ducts $\left({ }^{\circ} \mathrm{C}\right)$,

$B_{s}$ is the supply conduction fraction (a heat exchanger efficiency that depends on the air flow rate through the ducts, the duct surface area and the duct insulation), and

$B_{r}$ is the return conduction fraction. 
In this study, the 152P calculations use this equation with changing values for leakage, equipment capacity and thermal conditions (temperatures and enthalpies). We also examine the impact of regain of duct losses. Regain accounts for energy that is lost from the duct but goes to conditioned space instead of outside and the effect of changed duct zone conditions (due to duct losses) on thermal losses from the building envelope. The regain is a simple multiplier of duct losses that depends on the relative thermal coupling between the duct zones and the conditioned space.

For comparison to the 152P-calculated effectiveness, a measured DE is also determined. The measured DE is defined as the capacity delivered through the registers divided by the cooling equipment capacity.

$$
D E_{\text {meas }}=\frac{\sum_{i} Q_{i} \rho_{i}\left(h_{i}-h_{i n}\right)}{E_{c a p}}
$$

where: $i$ is an index that goes from 1 to the number of supply registers

$Q_{i}$ is the air flow through supply register $i\left(\mathrm{~m}^{3} / \mathrm{s}\right)$,

$\rho_{i}$ is the density of air flowing through supply register $i\left(\mathrm{~kg} / \mathrm{m}^{3}\right)$,

$h_{i}$ is the enthalpy of air flowing through supply register $i(\mathrm{~J} / \mathrm{kg})$, and

A propogation of error analysis on the terms in Equation 2, based on the uncertainty of input measurements, suggests errors in the mesured DE of $3-7 \%$.

\section{OVERVIEW OF FIELD MEASUREMENTS}

The diagnostic tests performed at each house were:

- Duct leakage using fan pressurization tests (using the procedures in proposed ASHRAE 152P)

- System fan flow (using the procedures in proposed ASHRAE 152P)

- Individual register flows (using a fan assisted flow hood technique)

- Measurement of duct surface area, and observation of duct type, location and insulation

- Continuous measurement of room, register, duct plenum, buffer zone, and outdoor temperatures and relative humidities

More details of these tests are given in Walker et al. (1998a, 1998b and 1999). These diagnostics were used as input to the Standard 152P calculation procedure and to determine measured delivery effectiveness.

\section{HOUSE DESCRIPTIONS}

Eleven houses were monitored for this project: two houses in Palm Springs, CA (sites PS1 and PS2), one house in Mountain View, CA (site MV3), two houses in Sacramento, CA (sites SA4 and SA5), a single house in Cedar Park, TX (site TX6) and five houses in Las Vegas, NV (sites LV7 - 11). All of the houses were new and unoccupied, except for MV3, which was new and recently occupied, and LV7, which was built approximately 10 years ago. Such a small number of houses were not considered to be a statistically valid sample of all houses but they do present a fairly wide range of different conditions for validation of the model. General information about these houses is summarized in Table 1.

Four of the Las Vegas houses were built with sealed attics with no intentional roof venting. The attic insulation in these homes was directly under the roof deck. This attic design should have a particular impact on duct effectiveness because the ducts are more in the conditioned space than in a conventional house with a vented attic and the insulation on the attic floor.

\section{DUCT CHARACTERIZATION}

Almost all of the homes in the study had all of the ducts located in the attic. The two exceptions were MV3 which had the return ducts in the garage and the supply ducts between the first and second floors, and TX6 which had some return ducting in an interior closet. All of the systems were constructed with plastic flex duct with R-4 (RSI-0.7) glass fiber insulation and had sheet metal or ductboard supply plenums. The return plenums were usually just an air handler cabinet, but in MV3 and TX6 a wood and gypsum wallboard box was built as a platform return for the air handler. An oddity at TX6 was that this return plenum contained the hot water heater. The location of the supply ducts, return ducts and air handler, as well as the duct surface areas in unconditioned spaces are given in Table 2. 
Table 1: House Locations, Characteristics, and Attic Descriptions

\begin{tabular}{|c|c|c|c|c|c|c|c|c|}
\hline \multirow[t]{2}{*}{ Site } & \multirow[t]{2}{*}{ Location } & \multicolumn{2}{|c|}{ Floor Area } & \multicolumn{2}{|c|}{ Volume } & \multirow[t]{2}{*}{ Attic Type } & \multicolumn{2}{|c|}{ Attic Insulation ${ }^{1}$} \\
\hline & & $\mathbf{f t}^{2}$ & $\left(\mathbf{m}^{2}\right)$ & $\mathrm{ft}^{3}$ & $\left(\mathbf{m}^{3}\right)$ & & & \\
\hline PS1 & Palm Springs, CA & 1440 & (134) & 14100 & (398) & Vented & $\mathrm{R}-30$ & (RSI-5.3) \\
\hline PS2 & Palm Springs, CA & 1440 & (134) & 14100 & (398) & Vented & $\mathrm{R}-30$ & (RSI-5.3) \\
\hline MV3 & Mountain View, CA & 1670 & $(155)$ & 15500 & (438) & Vented & $\mathrm{R}-30$ & (RSI-5.3) \\
\hline SA4 & Sacramento, CA & 880 & $(82)$ & 11100 & (314) & Vented & R-30 & (RSI-5.3) \\
\hline SA5 & Sacramento, CA & 1010 & (94) & 8900 & (253) & Vented & R-30 & (RSI-5.3) \\
\hline TX6 & Cedar Park, TX & 1530 & (142) & 12300 & (347) & Vented & $\mathrm{R}-30$ & (RSI-5.3) \\
\hline LV7 & Las Vegas, NV & 1300 & (120) & 11300 & (319) & Vented & R-19 & (RSI-3.3) \\
\hline LV8 & Las Vegas, NV & 2400 & (223) & 24700 & (700) & Sealed & $\mathrm{R}-19$ & (RSI-3.3) \\
\hline LV9 & Las Vegas, NV & 2030 & (188) & 20100 & (569) & Sealed & $\mathrm{R}-19$ & (RSI-3.3) \\
\hline LV10 & Las Vegas, NV & 2400 & (223) & 24800 & (701) & Sealed & $\mathrm{R}-19$ & (RSI-3.3) \\
\hline LV11 & Las Vegas, NV & 2010 & (186) & 19900 & (564) & Sealed & $\mathrm{R}-19$ & (RSI-3.3) \\
\hline
\end{tabular}

Table 2: Duct Locations and Surface Areas (in Unconditioned Zones)

\begin{tabular}{|c|c|c|c|c|c|c|c|}
\hline \multirow{2}{*}{$\begin{array}{r}\text { Site } \\
\text { PS1 }\end{array}$} & \multirow{2}{*}{$\begin{array}{c}\begin{array}{c}\text { Supply Duct } \\
\text { Location }\end{array} \\
\text { Attic }\end{array}$} & \multirow{2}{*}{$\begin{array}{c}\begin{array}{c}\text { Return Duct } \\
\text { Location }\end{array} \\
\text { Attic }\end{array}$} & \multirow{2}{*}{$\begin{array}{c}\begin{array}{c}\text { Air Handler } \\
\text { Location }\end{array} \\
\text { Attic }\end{array}$} & \multicolumn{2}{|c|}{$\begin{array}{c}\text { Supply Duct } \\
\text { Surface Area } \\
\mathbf{f t}^{2} \quad\left(\mathbf{m}^{2}\right) \\
\end{array}$} & \multicolumn{2}{|c|}{$\begin{array}{c}\text { Return Duct } \\
\text { Surface Area } \\
\mathbf{f t}^{2} \quad\left(\mathbf{m}^{2}\right) \\
\end{array}$} \\
\hline & & & & 364 & (33.8) & 102 & $(9.5)$ \\
\hline PS2 & Attic & Attic & Attic & 364 & (33.8) & 102 & $(9.5)$ \\
\hline MV3 & Between Floors & Garage & Garage & 10 & $(0.9)$ & 86 & $(8.0)$ \\
\hline SA4 & Attic & Attic & Attic & 243 & (22.6) & 76 & $(7.1)$ \\
\hline SA5 & Attic & Attic & Attic & 291 & $(27.0)$ & 76 & (7.1) \\
\hline TX6 & Attic & Closet & Closet & 387 & $(36.0)$ & 0 & (0) \\
\hline LV7 & Attic & Attic & Attic & 236 & (21.9) & 21 & (2.0) \\
\hline LV8 & Sealed Attic & Sealed Attic & Sealed Attic & 571 & $(53.0)$ & 58 & (5.4) \\
\hline LV9 & Sealed Attic & Sealed Attic & Sealed Attic & 365 & (33.9) & 19 & (1.8) \\
\hline LV10 & Sealed Attic & Sealed Attic & Sealed Attic & 796 & (74.0) & 52 & $(4.8)$ \\
\hline LV11 & Sealed Attic & Sealed Attic & Sealed Attic & 365 & (33.9) & 19 & $(1.8)$ \\
\hline
\end{tabular}

Duct leakage measurements were made in each of these houses using the two fan pressurization techniques from proposed ASHRAE Standard 152P. The first test simply pressurizes the duct system and determines the total duct leakage. The second technique also pressurizes the house to determine the duct leakage to outside. The standard specifies that the operating condition pressures be estimated using half the plenum pressure. In this study, the characteristic operating condition pressures were the average of the plenum operating pressure and the average register static pressure for the supply, and return plenum pressure for the return. The use of the additional supply register pressures could increase the accuracy of the test for systems with significant register boot leakage.

Air handler flows used in the calculation procedure were determined by pressure matching (the method in Standard 152P.) This method consists of routing the return flow through a calibrated fan, and matching the supply plenum pressure. The air handler fan flows were also measured using tracer gas in six of the houses.

The duct leakage results were normalized with the measured air handler flows in order to express the duct leakage as a fraction of air handler flow. Four different leakage fractions are reported in Table 3: the total duct leakage fractions for both the supply and the return ducts as well as the leakage fraction to outside for both the supply and the return ducts. 
Table 3: Air Handler Flow and Duct Leakage

\begin{tabular}{|c|c|c|c|c|c|c|c|}
\hline \multirow[b]{3}{*}{ Site } & \multirow[b]{3}{*}{ Condition } & \multirow{3}{*}{\multicolumn{2}{|c|}{$\begin{array}{l}\text { Air Handler Flow } \\
\text { CFM }\left(\mathrm{m}^{3} / \mathrm{s}\right)\end{array}$}} & \multicolumn{4}{|c|}{ Leakage Fractions } \\
\hline & & & & \multicolumn{2}{|c|}{ To Outside } & \multicolumn{2}{|c|}{ Total } \\
\hline & & & & Supply & Return & Supply & Return \\
\hline PS1 & As Found & 1861 & $(0.878)$ & $4 \%$ & $4 \%$ & $8 \%$ & $6 \%$ \\
\hline PS1 & Sealed & 1817 & $(0.858)$ & $3 \%$ & $2 \%$ & $4 \%$ & $4 \%$ \\
\hline PS2 & As Found & 1962 & $(0.926)$ & $4 \%$ & $2 \%$ & $7 \%$ & $4 \%$ \\
\hline PS2 & Leaks Added & 1774 & $(0.837)$ & $11 \%$ & $12 \%$ & $16 \%$ & $14 \%$ \\
\hline PS2 & Sealed & 1970 & $(0.930)$ & $2 \%$ & $2 \%$ & $5 \%$ & $4 \%$ \\
\hline MV3 & As Found & 1504 & $(0.710)$ & $15 \%$ & $16 \%$ & $22 \%$ & $18 \%$ \\
\hline MV3 & Sealed & 1453 & $(0.686)$ & $7 \%$ & $7 \%$ & $13 \%$ & $8 \%$ \\
\hline SA4 & As Found & 1361 & $(0.642)$ & $6 \%$ & $6 \%$ & $7 \%$ & $8 \%$ \\
\hline SA4 & Leaks Added & 1231 & $(0.581)$ & $11 \%$ & $18 \%$ & $13 \%$ & $21 \%$ \\
\hline SA5 & As Found & 1260 & $(0.595)$ & $8 \%$ & $8 \%$ & $10 \%$ & $10 \%$ \\
\hline SA5 & Sealed & 1240 & $(0.585)$ & $2 \%$ & $6 \%$ & $4 \%$ & $8 \%$ \\
\hline TX6 & Leaks Added & 1415 & $(0.668)$ & $7 \%$ & $4 \%$ & $8 \%$ & $14 \%$ \\
\hline LV7 & As Found & 1381 & $(0.652)$ & $7 \%$ & $2 \%$ & $7 \%$ & $3 \%$ \\
\hline LV8 & As Found & 1944 & $(0.917)$ & $3 \%$ & $1 \%$ & $9 \%$ & $1 \%$ \\
\hline LV9 & As Found & 1755 & $(0.828)$ & $4 \%$ & $2 \%$ & $8 \%$ & $8 \%$ \\
\hline LV10 & As Found & 1455 & $(0.687)$ & $4 \%$ & $1 \%$ & $8 \%$ & $1 \%$ \\
\hline LV11 & As Found & 1061 & $(0.501)$ & $2 \%$ & $1 \%$ & $9 \%$ & $5 \%$ \\
\hline AVERAGE & & 1556 & $(0.734)$ & $6 \%$ & $5 \%$ & $9 \%$ & $8 \%$ \\
\hline
\end{tabular}

These houses had on average, about $6 \%$ supply duct leakage to the exterior and about $9 \%$ total supply leakage. The return side showed similar results: on average $5 \%$ to the exterior and $8 \%$ total. These ducts, even only considering the as found condition for each house, are less leaky than houses that LBNL has measured in the past, e.g., Jump et al. (1996) measured an average of 17\% supply and $17 \%$ return leakage for 25 houses in California. Walker (1998) summarizes duct leakage measurements by other researchers that were of a similar magnitude to Jump et al. (1996). At several sites with very tight duct systems (PS2, SA4, TX6), holes were added to the duct system in order to be able to determine the effect of changing duct leakage on delivery effectiveness. The additional leaks were added at the plenums because of the difficulty of adding leaks to the plastic flexible ducts that comprised the majority of these systems.

\section{AIR CONDITIONER CAPACITY}

Air conditioner capacity was determined in three ways.

1. Nominal Capacity was estimated from the model number of the outdoor unit of the air conditioner (condenser and compressor).

2. ARI Capacity was obtained from the ARI (or equivalent) directory and represents the tested and simulated capacity at $80{ }^{\circ} \mathrm{F}\left(26.7{ }^{\circ} \mathrm{C}\right)$ indoor dry bulb, $67^{\circ} \mathrm{F}\left(19.4{ }^{\circ} \mathrm{C}\right)$ indoor wet bulb (corresponding to an indoor enthalpy of $32 \mathrm{BTU} / \mathrm{lb}(53.8 \mathrm{~kJ} / \mathrm{kg}))$ and $35^{\circ} \mathrm{C}\left(95^{\circ} \mathrm{F}\right)$ outdoor dry bulb.

3. Measured Capacity was calculated as the enthalpy change across the equipment multiplied by the mass flow through the air handler.

The nameplate, ARI, and measured capacity and the conditions for the measured capacity are summarized in Table 4. All reported measured capacities and conditions are averages over the last 5 minutes of a very long (1+ hour) air conditioning cycle (i.e. near steady state conditions) for one day at each site. Because capacity measurements were made for many days at each site, the measurements in Table 4 represent a value for typical conditions at each site. In most cases the measured capacity was lower than ARI capacity because the weather and/or indoor conditions during the study were less favorable to air conditioner performance than ARI conditions. Additionally, the ARI procedure assumes that the equipment has the manufacturers recommended refrigerant charge 
levels and air flows: several of the units did not. Furthermore, the indoor coil was not always matched to the outdoor coil, which can lead to further deviations from the ARI capacity. The one exception was MV3 in its sealed condition, where the measured capacity was higher than the ARI capacity. This is one case where the actual conditions, and system air flow and charge levels were more favorable for cooling system performance than the ARI conditions.

Table 4: Air Conditioner Capacity and Conditions

\begin{tabular}{|c|c|c|c|c|c|c|c|c|c|c|}
\hline \multirow[t]{2}{*}{ Site } & \multirow[t]{2}{*}{ Condition } & \multirow{2}{*}{$\begin{array}{c}\text { Nominal } \\
\text { Capacity } \\
\text { Tons } \\
\end{array}$} & \multicolumn{2}{|c|}{ ARI Capacity } & \multicolumn{2}{|c|}{$\begin{array}{c}\text { Measured } \\
\text { Capacity }\end{array}$} & \multicolumn{2}{|c|}{$\begin{array}{c}\text { Outdoor } \\
\text { Temperature }\end{array}$} & \multicolumn{2}{|c|}{ Indoor Enthalpy } \\
\hline & & & Btu/h & $(\mathbf{k W})$ & Btu/h & $(\mathbf{k W})$ & ${ }^{\circ} \mathbf{F}$ & $\left({ }^{\circ} \mathbf{C}\right)$ & BTU/lb & $(\mathrm{kJ} / \mathrm{kg})$ \\
\hline PS1 & As Found & 5 & 52800 & (15.5) & 50000 & (14.7) & 78.0 & (25.6) & 26.4 & (43.5) \\
\hline PS1 & Sealed & 5 & 52800 & (15.5) & 40000 & (11.7) & 85.7 & (29.8) & 23.9 & $(37.8)$ \\
\hline PS2 & As Found & 5 & 52800 & (15.5) & 39800 & (11.7) & 81.7 & (27.6) & 23.0 & $(35.7)$ \\
\hline PS2 & Leaks Added & 5 & 52800 & $(15.5)$ & 38200 & (11.2) & 84.0 & (28.9) & 23.3 & $(36.5)$ \\
\hline PS2 & Sealed & 5 & 52800 & $(15.5)$ & 34700 & $(10.2)$ & 95.6 & $(35.3)$ & 24.7 & $(39.7)$ \\
\hline MV3 & As Found & 3.5 & 39600 & (11.6) & 37700 & (11.0) & 81.8 & $(27.7)$ & 28.0 & $(47.2)$ \\
\hline MV3 & Sealed & 3.5 & 39600 & (11.6) & 44400 & (13.0) & 73.3 & (23.0) & 25.3 & (40.9) \\
\hline SA4 & As Found & 2 & 21600 & $(6.3)$ & 20800 & $(6.1)$ & 75.6 & (24.2) & 23.4 & $(36.7)$ \\
\hline SA4 & Leaks Added & 2 & 21600 & (6.3) & 19700 & $(5.8)$ & 75.0 & (23.9) & 23.4 & $(36.7)$ \\
\hline SA5 & As Found & 2.5 & 28800 & (8.4) & 26100 & (7.6) & 69.8 & (21.0) & 22.8 & $(35.3)$ \\
\hline SA5 & Sealed & 2.5 & 28800 & $(8.4)$ & 26600 & (7.8) & 79.4 & (26.4) & 23.0 & (35.7) \\
\hline TX6 & Leaks Added & 3 & 36000 & (10.6) & 27200 & (8.0) & 75.0 & (23.9) & 22.7 & (34.9) \\
\hline LV7 & As Found & 3.5 & 41000 & (12.0) & 28900 & (8.5) & 74.6 & (23.7) & 22.4 & $(34.2)$ \\
\hline LV8 & As Found & 4 & 48000 & (14.1) & 38700 & (11.3) & 85.8 & (29.9) & 22.9 & $(35.4)$ \\
\hline LV9 & As Found & 4 & 48000 & (14.1) & 26000 & (7.6) & 85.0 & $(29.5)$ & 23.5 & (38.4) \\
\hline LV10 & As Found & 3 & 35000 & (10.3) & 34100 & (10.0) & 86.0 & (30.0) & 25.1 & $(40.5)$ \\
\hline LV11 & As Found & 2 & 24000 & $(7.0)$ & 22100 & $(6.5)$ & 80.7 & (27.1) & 24.6 & (39.3) \\
\hline
\end{tabular}

\section{P EFFECTIVENESS CALCULATIONS}

For Standard 152P, the delivery effectiveness is based on seven principal input parameters: duct location, climate, duct insulation, duct surface area, system fan flow, equipment capacity, and duct leakage. Standard 152P uses leakage to outside for efficiency calculations because leakage to inside is not counted as an energy loss. Because the field tests in this study measure flows at the supply registers and do not take account of supply air leaks that reach the conditioned space instead of being lost to outside, we used the total duct leakage for supply leaks and leakage to outside for returns. Using this approach allows more direct comparison of the measured and 152P delivery effectiveness.

The following additional parameters are also used in the Standard 152P calculation:

- $\quad$ presence of radiant barriers

- reduced absorbtivity exterior roof coatings, or roof tiles

- venting condition of attics and/or crawlspaces

- thermal properties (surface areas, insulation, ventilation) of the building and duct location envelopes

The insulation and measured component areas were used to estimate regain factors using the method shown in the draft standard. However, because we are comparing 152P predictions to the energy in the air flow out of the registers we did not include the regain through the house/duct zone interface as required in 152P. Including this additional regain would have resulted in the calculated values being biased high because the energy flows out of the registers do not include this regain effect.

To evaluate $152 \mathrm{P}$, the sensitivity to the following input parameters was determined: 
- Climate and duct location temperatures were either measured local climate and duct location temperatures from the field tests or the tabulated values in $152 \mathrm{P}$.

- Capacity for air conditioning equipment was either the measured equipment capacity or ARI rated capacity.

- Regain of energy to the ducts was either calculated based on the surface areas and insulation levels of the duct zone or the default 152P values given in Appendix $\mathrm{H}$ of the standard. Note that the subsequent public review removed these defaults for regain from the standard and a calculation is now required. However, most users of the draft standard have been using these default values (e.g. CEC, 1998), so our comparison here is still a useful one.

152P calculations were performed for 3 different cases:

1. Default climate, default regain, and ARI capacity

2. Measured weather and indoor conditions, calculated regain from duct and duct zone U-values and areas, and ARI capacity

3. Measured weather, duct zone and indoor conditions, and capacity

Case 3 includes no formal calculation of regain, but still includes regain effects by using the measured temperature of the duct zones. Regain effect includes two components: 1) the energy lost from the ducts to the duct zone and 2) the energy flow from the duct zone to the house. Using the measured duct zone temperatures allows both effects to be treated separately. We expect Case 3 to be the most accurate because it has the most measured data being input to the model.

\section{MODELED-MEASURED COMPARISON RESULTS}

The measured and calculated delivery effectiveness results are summarized in Table 5.

Table 5: Measured and Modeled Delivery Effectiveness

\begin{tabular}{|c|c|c|c|c|c|c|c|c|c|}
\hline \multirow[t]{2}{*}{ Site } & \multirow[t]{2}{*}{ Condition } & \multirow[t]{2}{*}{$\begin{array}{l}\text { No. } \\
\text { of } \\
\text { tests }\end{array}$} & \multirow[t]{2}{*}{$\begin{array}{c}\text { Measured } \\
\text { Delivery } \\
\text { Effectiveness }\end{array}$} & \multicolumn{3}{|c|}{$\begin{array}{c}\text { Delivery Effectiveness } \\
\text { Calculated Using proposed } \\
\text { ASHRAE Standard 152P }\end{array}$} & \multicolumn{3}{|c|}{ Difference From Measured } \\
\hline & & & & Case 1 & Case 2 & Case 3 & Case 1 & Case 2 & Case 3 \\
\hline PS1 & As Found & 1 & $88 \%$ & $75 \%$ & $86 \%$ & $85 \%$ & $-14 \%$ & $-2 \%$ & $-4 \%$ \\
\hline PS1 & Sealed & 9 & $88 \%$ & $77 \%$ & $83 \%$ & $78 \%$ & $-10 \%$ & $-5 \%$ & $-10 \%$ \\
\hline PS2 & As Found & 1 & $76 \%$ & $79 \%$ & $84 \%$ & $82 \%$ & $3 \%$ & $7 \%$ & $6 \%$ \\
\hline PS2 & Leaks Added & 3 & $70 \%$ & $63 \%$ & $66 \%$ & $67 \%$ & $-7 \%$ & $-4 \%$ & $-3 \%$ \\
\hline PS2 & Sealed & 4 & $81 \%$ & $80 \%$ & $84 \%$ & $75 \%$ & $-1 \%$ & $3 \%$ & $-6 \%$ \\
\hline MV3 & As Found & 2 & $88 \%$ & $77 \%$ & $82 \%$ & $65 \%$ & $-11 \%$ & $-6 \%$ & $-23 \%$ \\
\hline MV3 & Sealed & 2 & $94 \%$ & $86 \%$ & $87 \%$ & $77 \%$ & $-8 \%$ & $-7 \%$ & $-17 \%$ \\
\hline SA4 & As Found & 7 & $90 \%$ & $61 \%$ & $71 \%$ & $80 \%$ & $-29 \%$ & $-19 \%$ & $-11 \%$ \\
\hline SA4 & Leaks Added & 3 & $87 \%$ & $28 \%$ & $47 \%$ & $66 \%$ & $-59 \%$ & $-40 \%$ & $-22 \%$ \\
\hline SA5 & As Found & 5 & $82 \%$ & $60 \%$ & $70 \%$ & $81 \%$ & $-22 \%$ & $-12 \%$ & $-1 \%$ \\
\hline SA5 & Sealed & 7 & $90 \%$ & $67 \%$ & $75 \%$ & $84 \%$ & $-22 \%$ & $-14 \%$ & $-5 \%$ \\
\hline TX6 & Leaks Added & 2 & $83 \%$ & $78 \%$ & $83 \%$ & $79 \%$ & $-6 \%$ & $0 \%$ & $-5 \%$ \\
\hline LV7 & As Found & 3 & $91 \%$ & $74 \%$ & $71 \%$ & $78 \%$ & $-17 \%$ & $-20 \%$ & $-13 \%$ \\
\hline LV8 & As Found & 3 & $82 \%$ & $91 \%$ & $85 \%$ & $84 \%$ & $9 \%$ & $3 \%$ & $2 \%$ \\
\hline LV9 & As Found & 3 & $89 \%$ & $92 \%$ & $88 \%$ & $85 \%$ & $2 \%$ & $-2 \%$ & $-5 \%$ \\
\hline LV10 & As Found & 3 & $83 \%$ & $87 \%$ & $80 \%$ & $77 \%$ & $3 \%$ & $-4 \%$ & $-6 \%$ \\
\hline LV11 & As Found & 3 & $82 \%$ & $89 \%$ & $84 \%$ & $84 \%$ & $7 \%$ & $2 \%$ & $1 \%$ \\
\hline \multicolumn{3}{|c|}{ Average $^{2}$} & $85 \%$ & $74 \%$ & $78 \%$ & $78 \%$ & $-11 \%$ & $-7 \%$ & $-7 \%$ \\
\hline \multicolumn{3}{|c|}{ Average Absolute Difference } & & & & & $13 \%$ & $9 \%$ & $8 \%$ \\
\hline
\end{tabular}

${ }^{T}$ Note that these are not fractional differences, but simply the difference Calculated DE-Measured DE

${ }^{2}$ These averages were computed before rounding. 
In most cases, the tests were repeated several times for each configuration - about three to four times on average. The results for each site and test condition are averages over these multiple tests. The As Found condition for TX6 was not used because there was not enough measured temperature data to calculate the measured DE. The percent differences between each calculated and measured delivery effectiveness are included, as well as the average and average absolute differences. The average difference shows the bias error whereas the absolute difference is an indicator of the precision of the prediction. Several cases were modified (see Discussion for details) and the corrected results appear in Table 6.

Table 6: Measured and Modeled Delivery Effectiveness with sites PS1, PS2, MV3, and LV7 corrected as in discussion and SA4 removed

\begin{tabular}{|c|c|c|c|c|c|c|c|c|c|}
\hline \multirow[t]{2}{*}{ Site } & \multirow[t]{2}{*}{ Condition } & \multirow[t]{2}{*}{$\begin{array}{l}\text { No. } \\
\text { of } \\
\text { tests }\end{array}$} & \multirow[t]{2}{*}{$\begin{array}{c}\text { Measured } \\
\text { Delivery } \\
\text { Effectiveness }\end{array}$} & \multicolumn{3}{|c|}{$\begin{array}{l}\text { Delivery Effectiveness } \\
\text { Calculated Using proposed } \\
\text { ASHRAE Standard 152P }\end{array}$} & \multicolumn{3}{|c|}{ Difference From Measured } \\
\hline & & & & Case 1 & Case 2 & Case 3 & Case 1 & Case 2 & Case 3 \\
\hline PS1 & As Found & 1 & $88 \%$ & $81 \%$ & $88 \%$ & $87 \%$ & $-7 \%$ & $-1 \%$ & $-2 \%$ \\
\hline PS1 & Sealed & 9 & $88 \%$ & $84 \%$ & $87 \%$ & $84 \%$ & $-4 \%$ & $0 \%$ & $-4 \%$ \\
\hline PS2 & As Found & 1 & $76 \%$ & $79 \%$ & $84 \%$ & $82 \%$ & $3 \%$ & $7 \%$ & $6 \%$ \\
\hline PS2 & Leaks Added & 3 & $70 \%$ & $66 \%$ & $69 \%$ & $70 \%$ & $-4 \%$ & $-1 \%$ & $0 \%$ \\
\hline PS2 & Sealed & 4 & $81 \%$ & $80 \%$ & $84 \%$ & $75 \%$ & $-1 \%$ & $3 \%$ & $-6 \%$ \\
\hline MV3 & As Found & 2 & $88 \%$ & $87 \%$ & $93 \%$ & $75 \%$ & $-1 \%$ & $5 \%$ & $-13 \%$ \\
\hline MV3 & Sealed & 2 & $94 \%$ & $98 \%$ & $100 \%$ & $89 \%$ & $4 \%$ & $5 \%$ & $-5 \%$ \\
\hline SA5 & As Found & 5 & $82 \%$ & $60 \%$ & $70 \%$ & $81 \%$ & $-22 \%$ & $-12 \%$ & $-1 \%$ \\
\hline SA5 & Sealed & 7 & $90 \%$ & $67 \%$ & $75 \%$ & $84 \%$ & $-22 \%$ & $-14 \%$ & $-5 \%$ \\
\hline TX6 & Leaks Added & 2 & $83 \%$ & $78 \%$ & $83 \%$ & $79 \%$ & $-6 \%$ & $0 \%$ & $-5 \%$ \\
\hline LV7 & As Found & 3 & $91 \%$ & $81 \%$ & $82 \%$ & $84 \%$ & $-10 \%$ & $-9 \%$ & $-7 \%$ \\
\hline LV8 & As Found & 3 & $82 \%$ & $91 \%$ & $85 \%$ & $84 \%$ & $9 \%$ & $3 \%$ & $2 \%$ \\
\hline LV9 & As Found & 3 & $89 \%$ & $92 \%$ & $88 \%$ & $85 \%$ & $2 \%$ & $-2 \%$ & $-5 \%$ \\
\hline LV10 & As Found & 3 & $83 \%$ & $87 \%$ & $80 \%$ & $77 \%$ & $3 \%$ & $-4 \%$ & $-6 \%$ \\
\hline LV11 & As Found & 3 & $82 \%$ & $89 \%$ & $84 \%$ & $84 \%$ & $7 \%$ & $2 \%$ & $1 \%$ \\
\hline \multicolumn{3}{|c|}{$\begin{array}{l}\text { Average }^{2} \\
\text { Average Absolute Difference }^{2}\end{array}$} & $85 \%$ & $81 \%$ & $83 \%$ & $81 \%$ & $\begin{array}{l}-3 \% \\
7 \%\end{array}$ & $\begin{array}{l}-1 \% \\
5 \%\end{array}$ & $\begin{array}{l}-3 \% \\
5 \%\end{array}$ \\
\hline
\end{tabular}

${ }^{T}$ Note that these are not fractional differences, but simply the difference Calculated $D E-$ Measured $D E$

${ }^{2}$ These averages were computed before rounding.

\section{DISCUSSION}

In general, it is to be expected that agreement would improve as more measured input data is utilized (increasing case number in Tables 5 and 6), and some of the sites have this general trend. On average, Case 2 and Case 3 have very similar levels of agreement, indicating that, on average, the results are insensitive to the use of either measured capacity or ARI capacity and either calculated regain or measured duct zone temperatures (although these factors can make a very large difference in an individual house). There are five sites (PS2, PS1, MV3, SA4, and LV7) where large discrepancies exist between calculated (using Case 3) and measured DEs. Data from these sites were investigated for measurement problems, and we concluded that in most cases, it is likely that the problem stems from the measurements of duct leakage.

At the first house in Palm Springs (PS1), the pressurization test showed very high cabinet leakage. The air handler cabinets were constructed with two sheet metal ends connected by steel corner pieces to create the frame of a rectangular box. Duct board pieces were used as panels to fill in the 4 sides to make a solid box. The edges where the duct board joined the metal pieces had no seals at all. These unsealed joints are what we hypothesize was causing the high cabinet leakage (106 $\mathrm{cm}\left(0.050 \mathrm{~m}^{3} / \mathrm{s}\right)$ at the supply plenum pressure) in the pressurization test. We theorize that not much flow leaked out of these locations in actual operation, i.e. the flow pattern was such that there was very little pressure difference in these locations. Removing this cabinet leakage from the calculations improves the modeled-measured agreement for Case 3 in the As Found condition slightly ( 2 percentage points) and shows 
significant improvement for the sealed Case (6 percentage points), where the cabinet leakage was the bulk of duct leakage.

Something similar may have happened at the second house in Palm Springs (PS2). The added air leakage flows at operating conditions were measured directly using a vane anemometer. The added holes were cut precisely to be the same size as the vane anemometer so that no traverses and interpolations were required. We found that this flow was considerably lower than the flow through these holes measured using duct pressurization techniques. This difference is because the momentum of the air flowing parallel to these large added holes reduces the flow through the holes compared to that expected from the size of the hole and the supply plenum static pressures. During the field measurements of these flows this phenomenon was anecdotally confirmed by field test personnel who noticed that much less air then expected (simply by feeling the flow with a hand near the hole) was flowing in and out through these leaks. The same phenomenon has also been anecdotally reported by other researchers. This raises concerns regarding systematic overprediction of duct leakage by the fan pressurization technique for all duct leaks (not just the added holes). To assess the magnitude of this effect, the duct leakage of the holes was assessed using the vane anemometer leakage flows, rather than the duct pressurization results. This improved the agreement for the Leaks Added condition by 3 percentage points for case 3 .

Mountain View (MV3) shows a large disparity between the calculated and measured delivery effectiveness. The most likely reason is that the pressurization test overestimates the leakage at actual operating conditions. For the pressurization tests, the two bathroom toe kick registers in this house were taped at the grille, including leakage from the under-sink cabinet. If we estimate the leakage in the supply duct by subtracting the sum of the register flows from the air handler flow, we come up with leakage that is about half of what the pressurization tests show. Calculations run with these lower duct leakage numbers improve the Case 3 agreement with measured DE by 10 percentage points for the As Found condition and 12 percentage points for the Sealed condition.

One of the Sacramento houses, SA4, is perplexing. The measured efficiencies are extraordinarily high, $90 \%$ for the as found condition and $87 \%$ for the added holes condition. Even when zero duct leakage is entered into the Standard 152P calculations, the DE falls one percent short in the As Found condition and two percent short in the Leaks Added condition of the measured DE. This leads us to believe that there is a problem with the measured DE, particularly associated with the register flow and temperature measurements for this site. For this reason, SA4 was excluded from subsequent analysis.

The discrepancy at site LV7 is largely related to the measurement of air handler cabinet leakage. This house had a leaky cabinet and these leaks were counted on the return side of the system. Although this was a good assumption for the new houses in the study, site LV7 was a much older system with a different configuration. In this house, the air handler was mounted at the end of the return plenum furthest from the equipment and almost all of the return plenum leaks were under positive pressure rather than negative pressure, and should have been counted as supply leaks. The results of new duct leakage test (called the DeltaQ test: see Walker et al. (2001)), also performed at this house, supports this argument. In fact, if the cabinet leakage is assumed to be on the supply side then the pressurization test results agree exactly with the DeltaQ results. Additional calculations have shown that counting the cabinet leakage on the supply site improves the agreement of Case 3 with the measured data by 6 percentage points.

Table 6 shows the results if these sites with leakage measurement problems are corrected, and the site with measured DE problems (SA4) removed from the analysis, both the biases and absolute errors are reduced by 2 to 7 percentage points. The problems at these sites aside, Standard 152P shows very good agreement for the cases that use the measured rather than the default weather. Using the ARI capacity instead of the measured capacity or using building component areas and U-values for regain do not significantly affect the agreement between modeled and calculated delivery efficiencies in many, but not all cases. Other researchers (Francisco and Palmiter, 1997; Andrews et al., 1998; Francisco and Palmiter, 2000) have pointed out the importance of accurate duct leakage and air flow measurements to using Standard 152P and the discrepancies discussed above confirm this.

Comparing Case 1 to Case 2 and 3 showed that using default values was not a great factor when averaged over all the tests, only adding one to two percentage points uncertainty. However, for an individual house the default conditions (particularly the weather) added about five percentage points to the difference. This result is as expected because the weather has a strong influence on the temperature of air surrounding the ducts for these attic systems. For other systems that are not so sensitive to climatic conditions (e.g., basement ducts), we expect this sensitivity to be minimized. It should be noted that the use of prescribed weather data in the standard means that it is not intended to be used to predict individual hourly efficiencies at specific sites, but rather to give good estimates at design and seasonal conditions.

Comparing Cases 2 and 3 showed only about one percentage point advantage for using measured duct location conditions and equipment capacity. This indicates that the simplifying assumptions about duct location 
temperatures and system capacity are not very critical (particularly when compared to other input parameters, such as duct leakage).

\section{CONCLUSION}

For the testsed houses, proposed Standard 152P is accurate for predicting delivery effectiveness to within 5\% if measured weather data is used and if the duct leakage and air handler flow are measured correctly and accurately. This is likely good enough for many applications, including code verification and energy use forecasting. However, the results suggest that the uncertainties become much larger if the duct leakage is poorly quantified. Four of the eleven test houses required modifications to the analysis of duct leakage measurements to get acceptable results, even though these measurements wer made in accordance with the procedures detailed in proposed Standard 152P. Comparison to measured results also suggests that using measured capacity (instead of ARI capacity) and measured duct zone temperatures (rather than calculated regain based on building components and U-values) does not significantly improve measurements. After this study was performed, several agencies (e.g. DOE, ASHRAE, and CIEE) have funded research to find improved duct air leakage measurement techniques that can be used in future work as well as be adopted by future versions of Standard 152. These new tests have the potential to greatly improve the accuracy of Standard 152P.

\section{ACKNOWLEDGEMENTS}

This work was supported by the Assistant Secretary for Energy Efficiency and Renewable Energy, Office of Building Technology, State, and Community Programs, of the U.S. Department of Energy under Contract No. DEAC03-76SF00098. The research reported here was funded by the California Institute for Energy Efficiency (CIEE), a research unit of the University of California. Publication of research results does not imply CIEE endorsement of or agreement with these findings, nor that of any CIEE sponsor.

The authors would like to acknowledge the fieldwork efforts of Darryl Dickerhoff, Duo Wang, Craig Wray, Chris Buchanan, Oscar Ortiz and David Montano.

\section{REFERENCES}

Andrews J W, Hedrick R L, Lubliner M R., et al. (1998) Reproducibility of ASHRAE Standard 152P: results of a round-robin test. ASHRAE Transactions, 104(1B), 1376-1388.

ASHRAE (1996) Systems and Equipment Handbook. Atlanta: American Society of Heating, refrigerating and AirConditioning Engineers

ASHRAE (2002) Second Public review Draft of Proposed ASHRAE Standard 152P - Method of test for Determining the Design and Seasonal Efficiencies of Residential Thermal Distribution Systems. Atlanta: American Society of Heating, Refrigerating and Air-Conditioning Engineers, Inc.

CEC (1998) Low-Rise Residential Alternative Calculation Method Approval Manual for 1998 Energy Efficiency Standards for Low-Rise Residential Buildings, California Energy Commission, Sacramento, California.

Davis B, Siegel J A, Francisco et al. (1998) Measured and modeled heating efffectiveness of eight natural gasheated homes. Seattle: Ecotope Inc.

Francisco P W, Palmiter L. (1997) A Technical review of ASHRAE Standard 152P. Seattle: Ecotope Inc.

Francisco P W, Palmiter L. (1998) Measured and modeled duct efffectiveness in manufactured homes: Insights for Standard 152P. ASHRAE Transactions, 104(1B), 1389-1401.

Francisco P W, Palmiter L. (2000) Field validation of Standard 152P. ASHRAE Transactions, 106(2), 771-783.

Jump D, Walker I S, Modera M P. (1996) Field Measurements of Efficiency and Duct Retrofit Effectiveness in Residential Forced Air Distribution Systems. Proc. ACEEE Summer Study 1996, pp. 1.147-1.157.

Proctor J P. (1998) Verification test of ASHRAE Standard 152P. ASHRAE Transactions, 104(1B), 1402-1410.

Siegel, Jeffrey, Davis R, Francisco P, et al. (1998) Measured Heating System Effficiency Retrofits in Eight Manufactured (HUD Code) Homes. Proc. ACEEE Summer Study1998, 2.189-2.201.

Walker I, Sherman M, Modera M, et al. (1998a). Leakage Diagnostics, Sealant Longevity, Sizing and Technology Transfer in Residential Thermal Distribution Systems. Berkeley: Lawrence Berkeley National Laboratory report \#41118. 
Walker I, Sherman M, Siegel J, et al. (1998b) Leakage Diagnostics, Sealant Longevity, Sizing and Technology Transfer in Residential Thermal Distribution Systems: Part II. Berkeley: Lawrence Berkeley National Laboratory report \# 42691.

Walker I. (1998c) Technical Background for Default Values used for Forced Air Systems in Proposed ASHRAE Standard 152P. ASHRAE Transactions, 104(1B), 1360-1375.

Walker I, Sherman M, Siegel J. (1999). Distribution Effectiveness and Impacts on Equipment Sizing. Berkeley: Lawrence Berkeley National Laboratory report \#43724.

Walker I S, Sherman M H, Wempen J et al. (2001) Development of a New Duct Leakage Test: Delta Q. Berkeley: Lawrence Berkeley National Laboratory report \#47308. 